MPIfG Journal Article

Leonhard Dobusch, Jakob Kapeller: "Why Is Economics Not an Evolutionary Science?" New Answers to Veblen's Old Question. In: Journal of Economic Issues 43(4), 867 - 898 (2009). Sharpe

The original publication is available at the publisher's web site: http://dx.doi.org/10.2753/jei0021-3624430403

The MPIfG Journal Articles series features articles by MPIfG researchers and visiting scholars published in peer-reviewed journals. Max Planck Institute for the Study of Societies (MPIfG) Cologne | www.mpifg.de

\title{
"Why is Economics not an Evolutionary Science?" New Answers to Veblen's Old Question
}

\section{Leonhard Dobusch and Jakob Kapeller}

\begin{abstract}
Addressing the question why Economics as a discipline is not subject to evolutive processes itself, we explain the paradigmatical dominance of neoclassical theories in Economics as a path dependent process. Recognizing economics as "locked into neoclassical thinking," we first identify three positive feedback mechanisms leading to strong barriers to paradigmatic change: coordination, complementarity, and learning mechanisms. In a second step, we show how actors strategically enforce these mechanisms via distinct "amplifiers." We then try to use this theoretical perspective to cursorily describe potentially path-breaking strategies.
\end{abstract}

Keywords: path dependency, paradigmatic dominance, pluralism

JEL Classification Codes: A11, B20, B52

About 110 years ago, when Thorstein Veblen first asked the question "Why is economics not an evolutionary science?" he characterized the economists of his age as "being still content to occupy themselves with repairing a structure and doctrines and maxims resting on natural rights, utilitarism and administrative expediency," to describe the traditional, axiomatic orientation of economic research (Veblen 1898, 347).

The main focus of his criticism is hereby twofold: On the one hand, he labels the classical economic theory as purely static and therefore unable to model the phenomenon of societal or economic change in an adequate way. Moreover, he castigates the use of the economic theory as "a projection of an ideal of conduct," which "is made to serve as a canon of truth" (Veblen 1898, 382). On the other hand, he criticizes the deterministic methods used by the lion's share of economists living in

Leonhard Dobusch is a Research Fellow in the Department of Management in the School of Business and Economics at Freie Universität Berlin and Jakoh Kapeller is a Research Fellow in the Department of Philosophy and Theory of Science at the Unisersity of Linz. The authors would like to thank John King, Heinz Kurz, Günther Ortmann, Walter Otsch and three anonymous reviearers for their helpful comments. They also thank the participants of the First Graz Schumpeter Summer Sithool for their suggestions. 
his age, which valiantly rule out the potential for identifying causalities relevant to processes of economic change, which are "always in the last resort a change in habits of thought" (Veblen 1898, 391).

Taking this last quote as a starting point for thinking about the dominant "habits of thought" in today's economic theory, one can depart from Veblen's original focus and address the question placed over this article from a related, but slightly different perspective. Instead of asking why the building blocks of (neo)classical economy do not follow evolutionary criteria - like Veblen did in his original work we are interested in finding out whether economics as a scientific discipline itself is evolving over time. This question should not be misunderstood as one that asks if economic theory has become better in some way or another. It is meant in a way that aims at qualitative changes in economics as a scientific enterprise, and therefore naturally has a paradigmatical dimension. When we assess the paradigmatical history of economics in terms of path dependence theory (David 1985; see also Sterman and Wittenberg 1999) we are actually harnessing the theoretical strand of economics that probably owes most to Veblen. His notion of "systemic obsolescence" and his portrayal of the British railway's lock-in to an inferior track gauge make him the legitimate ancestor of today's path dependence theory (Veblen 1915). With our application of contemporary path dependence theory to the discipline of economics, we not only want to value that tradition but we also hope to give valuable indications concerning the relation between alternative (often labeled "heterodox" or "dissenting") and neoclassical economics.

\section{Why Economics is Locked into Neoclassical Thinking}

Today the dominance of neoclassical economics is hard to overlook, nearly every (under)graduate course book is written from a neoclassical viewpoint. ${ }^{1}$ Neoclassical economists, journals and meetings dominate most of the scientific field. Nonmainstream topics in research and teaching are - especially for newcomers such as (under)graduate and postgraduate students - quite scarce and mostly limited to several specific universities and curricula. It is therefore not really surprising that neoclassical economists are often viewed as dominant actors seeking to diminish possible theoretical alternatives within the academic field. "The dominance of neoclassical economics has overshadowed the development and growth of alternative approaches to economics concerned with analyzing, rather than abstracting from, the complexities of economic systems associated with the interaction of economic, historical, social, legal, political and psychological factors" (Michie, Oughton and Wilkinson 2002, 363-364).

Thereby most of the basic conceptions and fundamental propositions, like utility maximization or perfect competition, which Veblen (1898) identified as "doctrines" of the discipline, are still - or better again - common sense in economic reasoning.

Contrariwise, one could object that we move on terminologically thin ice by using the concept of a neoclassical paradigm. First, the problem with the Kuhnian 
notion of paradigm is that we often lack an appropriate definition of what is meant by introducing this concept. ${ }^{2}$ Since we are concerned with economic theory we follow the criteria introduced by Roger Backhouse (2000) to terminologically separate heterodoxy and orthodoxy in economics. Backhouse' historical approach identifies (1) self-identification (the individual decision to be a heterodox economist), (2) sociology (existence of a specific set of relevant journals, conferences, associations etc.) and (3) core theoretical beliefs (mostly an axiomatic set of propositions about the nature of the economy). Since our assessment is from the perspective of philosophy of science and focusing on a much broader phenomenon relative to the different heterodox economic schools (namely identifying a neoclassical orthodoxy), we propose modifying the criteria Backhouse suggests for detailed historical reconstruction. Given these three criterions - self-identification, sociology and core metaphors - we are not only able to differentiate between orthodoxy and heterodoxy, which is our main aim, but these criterions may also prove useful for possible further differentiations within the heterodox camp.

While throughout this paper we surely emphasize the importance of sociological factors (2), we do not regard the criterion of self-identification (1) as necessary for defining neoclassical economists for two reasons. First, since the neoclassical paradigm constitutes orthodoxy (or otherwise: the mainstream) "normal" or "good" economics is often directly associated with neoclassical methods, axioms and style, in many cases constituting the borders of the economic discipline. Therefore, many mainstream economists do not view themselves as being neoclassical - but just as (normal) economists - in spite of accepting neoclassical axioms as the standard way of economic thinking. Symmetrically, heterodox economists, often marginalized in their surroundings, have a common tendency to advocate for and identify much more with their theoretical approach. The criterion of self-identification is therefore relevant for identifying those consciously deviating from mainstream, but not for those, who are part of it. Regarding the third criterion (3), we suggest to reinterpret this as core metaphors constituting the general patterns behind the theoretical structure as it is conventionally presented. Interpreting core theoretical propositions as metaphors is crucial for understanding the idiosyncrasies of a paradigm. The central metaphors of neoclassical theory, like the machine (suggesting an efficient working order; see Mirowski 1989), ${ }^{3}$ the equilibrium (implying order and optimality at once) or rationality (coming with a whole bunch of utilitarian ballast), are constitutive for its axiomatic foundations. If some of the axioms generated out of these metaphors are modified in order to produce new scientific puzzles by axiomatic variation this does not mean that they are abandoned. In fact, often the opposite holds. The underlying metaphors are strengthened through their broad applicability. We will look at this argument in detail later. The important thing about metaphors is that they have more than one meaning (Lakoff and Johnson 1980). For example, the central metaphor of the Ptolemaic vision of the planetary system - namely that earth constitutes its center - had not only scientific, but also many other societal, cultural and religious implications. The central metaphors of economic theory similarly have nor only scientific implications (resulting in the axioms traditionally discussed; cf. Colander, Holt and Rosser 2004), but also consequences for philosophy, politics, ethics or medicine. 
Even more important than a clear notion of the term paradigm is a concise understanding of "neoclassic": Recently, it has been argued (Colander 2000; Colander, Holt and Rosser 2004) that the term neoclassical is no longer adequate to describe mainstream economics. The reasons given for this are threefold. First, research programs partially contradicting basic neoclassical assumptions are accepted within the economic mainstream. Second, many prominent economists are not easily identified as "completely" orthodox neoclassical economists ${ }^{4}$ and, third, today's economics is thus much different from the neoclassical economics of the 1950s and 1960s. This would leave only a common methodological narrowness to identify a neoclassical or orthodox paradigm (as emphasized by Dow 2000 and Lawson 2006).

We object to this view of the recent development in economics or at least think that the arguments outlined above are of minor relevance for the assessment undertaken here. The new research programs ${ }^{5}$ in the recent economic mainstream most prominently experimental economics and the theory of asymmetric information - do not seriously question neoclassical hegemony. As all these approaches start with the standard neoclassical assumptions (cf. Osterloh 2008) and only modify certain aspects of the well-known axiomatic structure, they are generating - in Kuhnian terms of philosophy of science - new puzzles to solve. The slight modification of a wellestablished axiomatic set does not constitute a paradigmatical change. Therefore, if the theory of asymmetric information alters the assumption of fully informed individuals or if experimental and psychological economists relax the assumption of perfect rationality they generate new fields for the application of neoclassical theory and methods. This axiomatic variation argument is partially also accepted among those, who question the usefulness of the term neoclassical: "Our argument is that modern mainstream economics is open to new approaches, as long as they are done with a careful understanding of the strengths of the recent orthodox approach and with a modeling methodology acceptable to the mainstream" (Colander, Holt and Rosser 2004, 492). ${ }^{6}$

This is why we question that some of the new, and partially inspiring, research programs in mainstream economics are really changing the standard axiomatic structure, not to speak of the underlying metaphors in which we are interested. Moreover, the acceptance of the most prominent example of a "new and disagreeing" research program - experimental economics - heavily depends on its orientation. If it uses the methods prescribed by neoclassical standards and if it does not claim to "falsify" (in Popperian terms) or "revolutionize" (in Kuhnian terms) neodassical economics, its welcome in the mainstream is much more courteous (see Sent 2004 and Samuelson 2005 to get a deeper picture). There is, thus, no doubt that results from experimental or behavioral economics factually challenge the standard economic model of human behavior demanding fundamental modifications of the traditional theoretical corpus as recently and prominently demonstrated by Kahneman, Diener and Schwarz (1999) or Layard (2006). Yet, this way the standard theoretical model still keeps functioning as the focal reference point, indicating its central role in the relevant discourse. 
A similar line of argument - varying assumptions, not contesting basic principles - can be pursued regarding the so-called "unorthodox" economists as we excluded the criterion of self-identification for mainstream economists exactly to avoid these "grey areas" (Dow 2000, 157) partially evoked by them. This, however, is no arbitrary choice but a theoretically grounded one. In paradigmatical terms it simply does not matter if an economist - working inside a certain paradigm - is a partially disagreeing or even dissenting and therefore an "unorthodox" economist, he is just part of the paradigm he works in. From a historical perspective this categorization may look crude, but eventually it is just a technical distinction.

Within the past 100 years economics has been paradigmatically dominated by (neo)classical economics, although the first 50 years would probably not justify speaking of a paradigmatical lock-in. Alternative paradigms such as Institutionalism in the United States were at least an equal competitor and neoclassical dominance was even interrupted by a short period of Keynesian spirit in the midst of the century. This kind of "temporal paradigm shift" was possible because of the historical background of the "Great Depression" and the presence of a more or less complete alternative theory (Keynes 1936). However, since the publication of Keynes' General Theory, neoclassical economists have devoted much time to theoretically "closing the ranks" of their discipline and institutional innovations such as quantitative citation metrics have reinforced their dominance already in place (for the latter see the section titled "Mechanism at Work \#2" below). Theoretically, neoclassical economists tried to reintegrate the Keynesian theory into a neoclassical framework (today often found under the labels of New-Keynesianism or the "Micro-Foundation of Macroeconomics" see Backhouse 2005; Blanchard 1999) indicating that "the restrictive monetary and fiscal policies were in fact a regression to the pre-Keynesian orthodoxies of the 1920s" (Michie, Oughton and Wilkinson 2002, 352). Similarly, Fusfeld (2000, 260) notes that "like the economic orthodoxy of the early decades of the twentieth century, today's orthodoxy ignores the structure of wealth and power and its implications for social and individual welfare."

In Kuhnian terminology (Kuhn [1962] 1996), the theoretical and empirical shortcomings of neoclassical theory can be referred to as anomalies, which challenge the prevailing paradigm constructed by a certain scientific theory or viewpoint. Following Kuhn, the dominant paradigm has three main options regarding how to deal with such anomalies, i.e., scientists representing the challenged theory always choose between

a) the solution of anomaties within the paradigm; or

b) the archiving of the anomalies for the next generations of researchers, who are hopefully "better equipped"; or

c) the (partial) withdrawal of the prevailing theory (in favor of possible theoretical alternatives).

Anyway, modern economic theory does not seem to care much about the Kuhnian views of scientific progress. Shortcomings or anomalies have often been known for many years (e.g., Sraffa 1926; Stigler 1957; Albert [1963] 1971; Kahneman and Tversky 1974; Keen 2001; Fulbrook 2004; Ziliak and McCloskey 2008) without 
any fundamental solution given by modern economists ${ }^{7}$ (which rules out option a). The neoclassical theory is not only still "in power," it is also often praised for its political relevance and prognostic accuracy (like in Willke 2003 or Breyer 2008, ruling out option c). The anomalies are often not even considered as such, and the imposed critique is not taken as a serious challenge by neoclassical economists. Furthermore, it seems reasonable to say that these well-known anomalies are not even "archived for future generations" (ruling out option b) - they are, boldly speaking, "ignored" as far as possible, $-\mathrm{a}$ fact that is not compatible with the Kuhnian approach to the analysis of scientific development, since Kuhn did not adapt his observations concerning paradigmatical developments to the instrumentalist notion of many scientific theories. The fictitious character of economic theories, which are mainly so-called as-if theories with an extensive ceteris paribus clause, ${ }^{8}$ often makes them immune to potentially falsifying empirical observations. But from the perspective of philosophy of science (partial) falsifications following Popper (1969) are a necessary precondition in order to define a set of unsolved problems as an anomaly. Therefore neoclassical economics does not encounter such anomalies, or more precise; since the falsifying observations are not conceived as such (due to the fictitious theoretical structure; this is obvious since Vaihinger [1911] 1986), neoclassical economists do not recognize them as anomalies (see Kapeller 2008 for an extensive treatment).

To further develop the Kuhnian approach and to correct this "blind spot" was the main aim of Imre Lakatos (1970) developing his concept of a scientific theory, consisting out of an "inner core," where the basic assumptions are fictitious and immune to falsifications, and a "protective belt" with auxiliary hypotheses related to the theory, which are falsifiable. He does not, however, (a) give any criteria as to how many auxiliary hypotheses have to be wrong in order to constitute an anomaly in Kuhnian terms and, therefore, (b) does not provide any help in determining whether a paradigm is worth working on (Chalmers 1989, 87-88). So in fact, the explanation of the dominance of some paradigm is left to the individual scientist or social conventions - depending on one's view of the scientific community.

Accounting for these considerations it seems reasonable to complement (or even: operationalize) Kuhns' resp. Lakatos' approach with some kind of mid-range theoretical concept as it was already done once by Sterman and Wittenberg (1999) analyzing the potential path dependence of a paradigm. When it comes to issues of technical or organizational change, researchers often relate to the concept of path dependence brought into the economic discourse by David (1985) and Arthur (1989) in order to explain the underlying (evolutive) processes: "We define . . . path dependency as a situation in which an individual actor or a group of actors have lost (at least partly) their power to choose among alternatives because a path reproduces a certain pattern of decisional behavior" (Sydow, Schreyögg and Koch 2005, 19).

If we interpret the economic community as a distinct group of actors sharing a common endeavor and compare this definition with the situation of economics sketched above, it seems that economics, at least since the 1970s, would qualify as "locked into the neoclassical paradigm" in terms of path dependence-theory. "I am unable to find any compelling reasons why economic analysis should remain "locked in' to an ahistorical conceptual framework" (David 2001). 
In this spirit, we will use the concepts provided by path dependence theory to analyze the creation of the neoclassical path in economics, the mechanisms responsible for the paradigmatical lock-in of neoclassical theory, and then discuss possibilities for "un-locking" economics from the neoclassical path.

\section{Emergence of Neoclassical Paradigmatical Dominance as a Case of Enhanced Path Creation}

Our interpretation of the paradigmatical history in economics is that the dominance of neoclassical economics had its most relevant theoretical starting point in the 1870 s, reflected by the contributions of Walras, Jevons and Menger at the end of the $19^{\text {th }}$ century (cf. Screpanti and Zamagni 1995, 145-175). These scholars developed the main paradigmatical cornerstones of neoclassical economics by providing a general and partially formal theory of market operations (Walras) and a urilitarian framework for individual decision-making (Jevons) based upon the idea that marginal values are those that matter (Menger). Therefore - in its beginning - neoclassical economics was a purely theoretical endeavor and had not gained much institutional power, but it was, probably because of its mechanistic elegance, already attractive for many scholars, who soon built up the theoretical code of conduct observed by Veblen:

The marginalist scholars working between the end of the nineteenth century and the early 1920 s conquered the academic circles of almost all Western countries, and contributed to the creation of a new, dominant theoretical system. . . . As early as the beginning of the twentieth century, pure economic theory was able to present itself as a doctrinal corpus; the turning point of the 1870 s finally produced a completely new theoretical system which still dominates the scene today. (Screpanti and Zamagni $1995,177-178)$

An illustrative example of what happened to divergent arguments in the economics of the early $20^{\text {th }}$ century - even when they were put forth by prominent economists - is Lionel Robbin's harsh critique of Alfred Marshall's metaphor of the "representative firm," which is a basic building block of Marshall's famous Principles and his economic theory including a heretic notion against neoclassical economics." Not least, it is for this reason that Robbins denounces the concept of the representative firm as "not merely unnecessary," but "positively misleading" (Robbins 1928, 398). Another interesting example is that even socialist economists were attracted by, or at least forced to present their results in a mode, compatible to the neoclassical theory - in this sense, the Polish socialist Oskar Lange "proved" the efficiency of a centrally planned economy by interpreting the auctioneer as a ministry of economic affairs (cf. Lange 1935).

These instructive examples of the inpressive impact of neoclassical theory demonstrate its status at the beginning of the $20^{\text {th }}$ century. Both - the liberal and neoclassical theologist Marshall and the socialist atheist Lange - had to adhere to the 
dominant scientific paradigm in order to be taken seriously. This illustrates that from the 1920s onward neoclassical economics became the dominant habit of thought, at least in the European and parts of the American economic community (cf. Screpanti and Zamagni 1995, 189-94), which is best demonstrated by a contemporary witness commenting on what he calls the classical way of economic thinking. "The difficulty lies, not in the new ideas, but in escaping from the old ones, which ramify, for those brought up as most of us have been, into every corner of our minds" (Keynes 1936, xii).

After World War II, the economic community was a bit more heterogeneous. Because of emigration, different schools of thought spread from Europe around the world, Keynesian theory began to become more influential in macroeconomic thinking and there was, as already mentioned, an influential group of institutional economists in the United States (Screpanti and Zamagni 1995, 282-285; see also Rutherford 2000).

Nevertheless, due to the seminal and path-shaping contributions of Popper (1957) complaining about the "poverty of historicism," Hayek's dystopia The Road to Serfdom (1944), Friedman's epistemological justification of neoclassical theory in the Essays in Positive Economics ([1953] 1966), Samuelson's famous textbook (Principlis of Economics, 1948), and Arrow and Debreu's military-financed welfare-analysis of market systems (1954), neoclassical economics got back on the track by gaining institutional power and soon became the most important player in the field (Ötsch 2008).

From the perspective of path dependence theory, the post-war situation depicted above constitutes a "process of path formation," which is principally open-nded ("non-ergodic," David 1985) meaning that there is the possibility of multiple, ex-ante unpredictable equilibria. In this sense, the process of path formation can be understood as a struggle for the right path (or paradigm). In this process, we have to take into account the possibility of "intentional path creation," in the sense that "powerful agents ally in order to generate the momentum necessary to create a new technological, institutional or (inter-)organizational path" (Sydow, Schreyögg and Koch 2005,31 ), a mechanism similar to processes of "path creation" via distributed agency as described by Garud and Karnxe (2003).

Neoclassical economics had - aside from the contributions mentioned above such a group of well organized and strategically acting economists on its side, which were (and partially still are) coordinated via the Mont Pelerin Society (MPS). ${ }^{10}$ This organization and its affiliates had an openly committed interest in confronting the "prevailing socialism" by influencing economic theory based on the belief that "what is essentially an ideological movement must be met by intellectual argument and the reassertion of valid ideals" (MPS 1947). More bluntly expressed this objective can be characterized - following the analysis of societal hegemony undertaken by Hayek (1949) and Lippmann ([1921] 1997) - as propagandistic motive indicating that one already "knew 'the truth'," the essential mission "was to evangelize" (Anthony Fisher, an important patron of the MPS and her sister organizations, in a letter, cited according to Cockett 1995, 139). 
In the subsequent years, the MPS was quite successful in raising a professional network of important economists and other scientists and relevant actors in media, industry and politics. One important aspect of this network was that its expansion not only relied on university departments but also - through successive funding by the "industrial part" of the network" - on the construction of privately organized "charity" research organizations, mainly labeled as think tanks. ${ }^{12}$ A quantitative illustration of the importance of this network is most easily reached by analyzing the growth of the MPS-related network of think-tanks as depicted in Figure 1 (the size of the think-tank-network is just a proxy of the importance of the MPS-network).

Figure 1. Development of the Network of MPS-Related Think Tanks in the Second Half of the Twentieth Century (data obtained from Walpen 2004, 402-404)

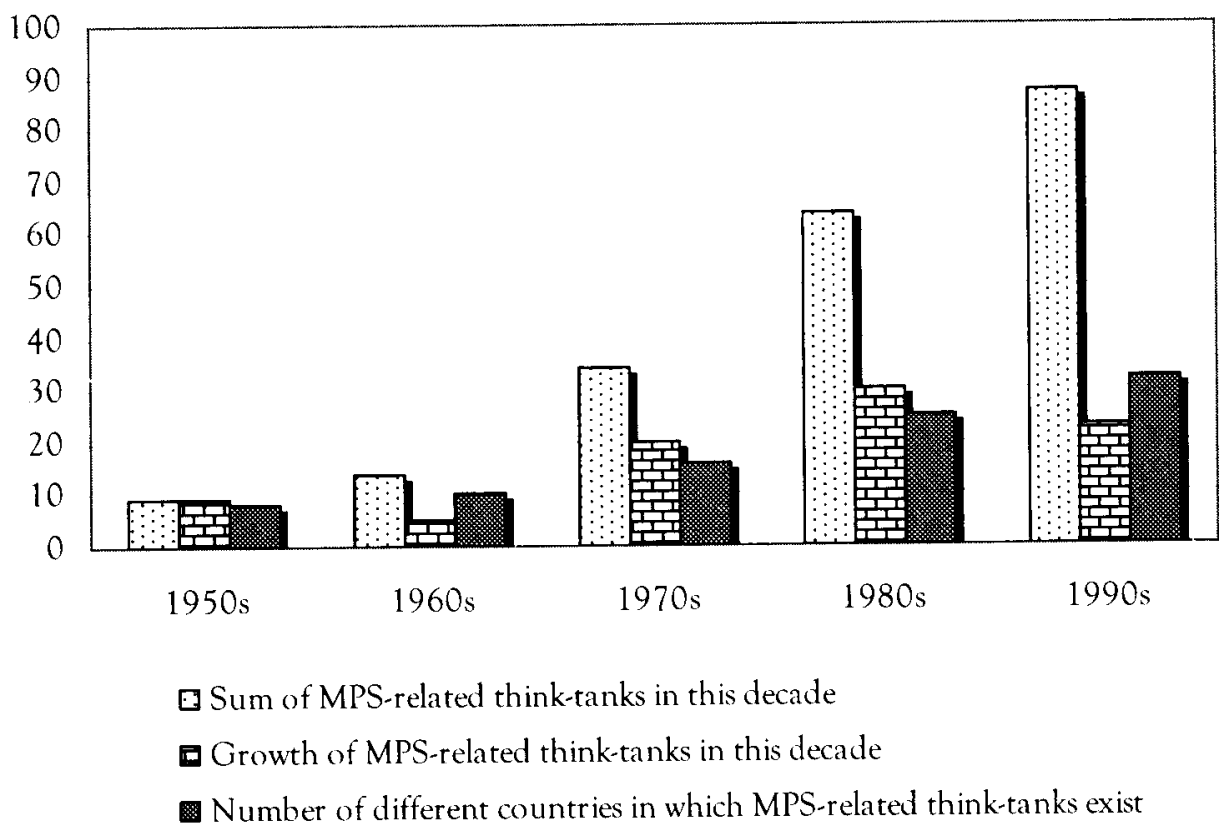

In addition, the Membership in the MPS has grown considerably from about 170 members in 1951 to roughly 500 (excluding those, who passed away) in 1991, mainly from the academic area. Although most participants in the network around the MPS do not apply for membership within ${ }^{13}$ - this indicates that the number of members is a very poor proxy for measuring the influence of the MPS - we can obtain some information about the professional distribution of the MPS-members. According to Walpen (2004), less than one third of the members are occupied in a think tank indicating that the part of the network consisting of think tanks is - 
despite its impressive size and distribution - only a small part of the total network. This is inline with the original strategy of the MPS, which relies more on the authority of academics and the power of university teaching to influence the upcoming intellectuals' from the beginning instead of penetrating them later on via a network of think tanks.

Be aware that it is no spiritual "conspiracy argument" that is put forward here. It is not argued that economics took the path of neoclassical theory because of the intentions of the MPS - in fact, some of the major MPS proponents such as Hayek himself ended up in the "heterodox camp" of the Austrian economic school. Nevertheless, we argue that the MPS and its sister organizations participated in a principally open process of path formation as an organized and not-negligible group with the common interest to exploit economic theory and its intellectual appearance for political purposes. In short, this path formation process consisted of several independent dynamics, which had complementary effects to the actions of the MPS. The role of Harvard University or MIT might serve as an example. While rejecting the political ambitions of the MPS, scholars of both groups agreed that neoclassical theory was most important for the development of economic theory, especially in microeconomics. In a recent article on his personal relation to Hayek, Paul Samuelson $(2009,3)$ articulates his denial of Hayek's political motive but concludes very similar to our interpretation: "I can bear witness that, for twentieth century professional economists, Milton Friedman was infinitely more important for turning economists toward conservatism than Hayek. For the lay public maybe Hayek may have been more important?"

Another independent development eventually reinforcing the intentions of the MPS includes weaknesses and mistakes in non-mainstream strands of research that contributed heavily to the conceptual neoclassical dominance. Within old institutionalism, for example, instinct analysis suffered from the fact that many authors suggested a multitude of often poorly founded instincts to explain human nature, thereby substantially discrediting this branch of research (see e.g., the criticism in Ayres 1958). ${ }^{14}$

Backhouse (2005, $385 \mathrm{ff}$.) referred to these independent developments as different "histories that can be written." In addition to "ideology" represented by the MPS, he mentions both "learning from mistakes" and "changes in the demand for economic ideas" in the 1970 s stagflation period, as well as "academic entrepreneurship," 15 "important individuals" (such as Arrow, Freedman or Hayek) and "the internal dynamics of the economics profession." It is particularly this "variety of histories" - consisting of both emergent and strategic elements - that is the central characteristic of the first (contingency) phase of any path dependent process as described by Sydow, Schreyögg and Koch (2005) and is the reason for its ex-ante unpredictability.

Therefore, it seems quite acceptable that economists who preferred neoclassical theory for scientific, ideological, or other reasons had a vital interest in participating in and affecting the openended process of path-formation and enhancing the paradigmatical status of neoclassical economics - a tendency reinforced by the openly 
committed political interests of the MPS, its members and affiliates. Even the influential publications mentioned above were significantly influenced by the liberal political motive within the MPS, as Nordmann (2005) points out. From this point on, the emergence of the neoclassical paradigm as the dominant path of economics can be understood as a case of enhanced path creation.

\section{Economics' Paradigmatic Development as a Path Dependent Process}

\section{A Simple Theoretical Framework of Path Dependency: Mechanisms and Amplifiers}

Applying the concept of path dependence on economics' paradigmatic development requires explaining the interplay between the subject matter and the institutional and social structure of the scientific community in economics with the help of the main theoretical features of path dependence (following Sydow, Schreyögg and Koch 2005 as well as Stermann and Wittenberg 1999). By looking at positive feedback mechanisms we try to explain how neoclassical dominance over time turned into paradigmatical lock-in. Most scholars dealing with path dependence as a theoretical approach ${ }^{16}$ suggest the following categories of mechanisms as (possibly) leading to situations of lock-in over time.

\section{Coordination / Direct Network Effects}

Coordination effects arise if the utility of an individual adopter of a technology or behavior increases with the total number of people adopting the same technology or behavior, like, for example, driving on the right hand side of the road. These effects are also referred to as direct network effects (North 1990; Ackermann 2001) and are often associated with production or organizational processes delivering increasing returns to scale (Arthur 1996).

\section{Complementarity / Indirect Network Effects}

The adoption and development of practices or institutions complementary to a technology or behavior increases the utility of adopting the technology or behavior itself (Dosi 1982; Katz and Shapiro 1985). For example, if there is a greater variety of software products, a computer may become more useful for some people. These effects are also called indirect network effects, which are also often associated with increasing returns to scale (Shapiro and Varian 1999).

\section{Learning / Irreversible Investments}

Learning effects arise if adopters have to adapt (to) a certain technology or behavior in order to increase their efficiency in handling a technology or behavior. In this case, it is easier to update the available knowledge than to learn a completely new 
scheme of handling/understanding, leading to accumulation of specific knowledge over time (Williamson 1985; Arthur 1996). ${ }^{17}$ This kind of cumulative investment in intransferable knowledge also parallels "sunk costs" as a frequent explanation of path dependent decisions and processes (Arrow 2003).

\section{Amplifier}

The designation "mechanism" implies an underlying logic that works more or less independently from the actor's interests and strategies. If adopting any system with network effects, one cannot avoid contributing to the adopted "camp." But as has been shown in the previous section on path creation, economics is not immune against strategic moves and exogenous interests and so is the functioning of the described mechanisms. While some observations can clearly be depicted as consequences of these mechanisms, others seem not to be a crucial part but an amplifier for the network, complementarity, and learning effects observed. ${ }^{18}$ The related mechanisms are, however, a precondition for the amplifiers to be effective. In other words, it is mutual reinforcement with the respective mechanism that makes these amplifiers more influential than ordinary strategic action. Taking into accuunt that economics has a considerable impact in shaping societal hegemony concerning economic policy, these amplifying strategies can also be named "hegemonial strategies."

\section{Mechanism at Work \#1: Increasing Returns and Network Effects in Economics}

It is more or less obvious that working inside the scope of the neoclassical paradigm has significant institutional advantages. If we assume that an average economist is not only interested in the "truth about the economic process" but also in getting a job more or less adequate to his or her ambitious studies, it is only wise not to depart too far from the dominant paradigm (Earl 1983). Similar things can be said about the possibility of earning research funds, publication possibilities, university curricula, or the probability of finding (a) supervisor(s) for a thesis. This can be understood as a direct network effect, creating immediate benefits when "joining" the neoclassical research community, stemming from "self-reinforcing feedback processes" (Sterman and Wittenberg 1999) inside the paradigm of neoclassical economics. From a sociological point of view, this can be interpreted as "mutual dependence" among scientists, meaning that "economists generally have to adhere to a dominant neoclassical strategic paradigm to be taken seriously" (Siler 2003, 1). This is backed by empirical studies concerning review processes in scientific publications (Bedeian 2003) suggesting that roughly one-quarter of all authors includes statements in their articles, which they normally would reject, in order to please the reviewers of the article in question. Even more, Davis (2007) reports that a majority (60\%) of respondents in his study among North-American economists agrees that "a "good-oldboy' network in the profession influences the probability of article acceptance." 
It is therefore not surprising that the acceptance of neoclassical macroeconomics and supply-side oriented arguments in the United States is increasing: "Specifically we found evidence of a shift toward more agreement with monetarist and new classical or supply-side-based propositions" (Fuller and Geide-Stevenson 2003, 383). ${ }^{19}$

But increasing returns to scale can, in this context, also be identified from a theoretical point of view. The successive effort in deepening neoclassical economic theory by many researchers around the world has given this branch a certain "starting advantage," which manifests itself in a surprisingly high explanatory power, especially when presented to non-economists. Similar to the Ptolemaian model of planetary movement, which at the beginning of the heliocentric worldview could yield much better predictions of the planets' trajectories than its successor (Kuhn [1962] 1996), ${ }^{20}$ neoclassical economics has developed sophisticated - and partially questionable methods in order to keep reality in line with theory. Taking Real Business Cycle (RBC) Theory as a prominent example for providing econometric estimations very close to the real data (like in King and Rebelo 2000), one must often concede that a certain "econometric creativity" is necessary in order to provide such results. In RBCTheory, it is, however, often the case that the difference between the estimation of the model and the real data - the residual - is understood as a measure of technological change and therefore reinserted in the model. This (necessarily) provides results of astonishing accuracy, but only little theoretical or practical relevance.

Moreover, there are various modifications of neoclassical theory to encounter certain streams of successive critique - an approach already discussed under the label of axiomatic variation. This strategy not only allows defending weaknesses and flaws of the present theory by arguing that the incorporation of a certain critique would only make the model more complicated but also continuously delivers new "unsolved puzzles," which are a paradigmatical advantage in a Kuhnian sense. Another example is the research done on the Multiple-Self-Theory, incorporating "curious inducements" in the homo oeconomicus' utility function in order to "explain" altruism, environmentalism or discrimination. Most of these new "unsolved puzzles" are created by altering one or two basic assumptions in the axiomatic framework of neoclassical economics delivering new theoretical problems to solve and assess. This broad scope of neoclassical economics can be interpreted as making "the system more attractive" (Dobusch and Schüßler 2007, 10) - and at the same time, easier to defend. In paradigmatical terms one could argue that puzzle creation through axiomatic variation is a strategic advantage.

The neoclassical network is thereby the only way for a researcher to reach the top of his or her discipline. No matter if we look at the top journals, the Nobel Prize for Economics or the top institutions of international policy making, an extensive knowledge about and a certain commitment to neoclassical economics serve as some kind of "minimum condition" for becoming recognized by those institutions. 


\section{Amplifier \#1: Get the prize}

As indicated previously, the Nobel Prize - as a central object of prestige not only in economics (Merton 1968) - is for several reasons a quasi-neoclassical one. First, the Nobel Prize for economics is, in fact, the "The Bank of Sweden Prize in Economic Sciences in Memory of Alfred Nobel" and is not funded by Nobel's heritage. Therefore, the criteria for getting the Nobel Prize in economics are defined by the Bank of Sweden and are different from the (political) criteria of the other Nobel Prizes. Second, the chairmen of the prize committee (Erik Lundberg, later Assar Lindbeck) have been members or associates of the Mont Pelerin Society (MPS) and advocates of consequent free market policies. Third, the implementation of the Nobel Prize for Economics was a project organized by the MPS in order to successively favor and promote the ideas of neoclassical economics (Ötsch 2008).

This implies that the Nobel Prize is also used as a strategic instrument ensuring the intellectual hegemony of an already dominant school in economics by serving as "a barrier for new thinking" (Söderbaum 2004). While one could still reply here that there is no evidence for such an ideological abuse of the Nobel Prize, a short look at the list of Nobel Prize winners in economics clarifies that there are very few of them who can be considered heterodox in their economic arguments. So, at least the opposite view - that the Nobel Prize has favored theoretical pluralism in one way or another - seems somehow hard to prove.

\section{Mechanism at Work \#2: Complementary Institutions and Collateral Consequences for Economics}

Although the "actual practice of science cannot be reduced to the implementation of methodological rules" (Miller 2004, 77; with reference to Popper's Logic of Scientific Discovery), there is a growing tendency across all areas of research to measure scientific quality and excellence via quantitative indexation. In Economics, the mere historical coincidence of the simultaneous rise of neoclassical paradigmatic dominance and citation indexing as a dominant measure for research quality and success has led to a situation of mutually reinforcing legitimation of both systems: the citation rankings as well as the neoclassical paradigm.

Research in general, and research publication in particular, follow a reputation logic Merton (1968) called the "Matthew Effect ${ }^{21}$;" those researchers who already have received a lot of recognition are likely to receive even more of it in the future. Whereas Merton described this effect using nobel laureates as examples, ${ }^{22}$ this pattern not only works for (or against) researchers, but also for (or against) journals and their reputation. The better the reputation of a journal, the more (prominent) people hand in their articles, the easier it is for the editors to acquire high-quality reviewers, the more it will be read and cited - which in turn increases the reputation of the journal even further. Economics is known for the tradition that the "big eight" ${ }^{23}$ dominate the boards of the most important journals, and that many of the authors in these journals are a part of the economics departments in one of these universities. 
Impressive evidence for the strength of this complementarity between journal reputation and intellectual rigidity within economics is also provided by Hodgson and Rothman (1999, F180), who speak of "institutional oligopoly" in describing the same issue and also refer to "path-dependent processes. . . Institutions with an initial concentration of editors or authors may benefit from processes of positive feedback involving, for example, an increasing ability to attract research grants, increasing visibility and reputation, increasing capacity to recruit leading researchers, and increasing research output."

This general dynamic has become institutionalized and hence reinforced from the 1960s onward by "objective" quantitative measures, like citation indexes or the Thomson Scientifics' "Journal Impact Factor." The latter ranks scientific journals related to the number of citations that their published papers received and results in the popular categorization of Journals from $A$ to $E$.

Journals ranked as "A" in most cases are very easily able to reproduce their top position, leading to a stable cluster of journals that mutually refer to one another and make it quasi impossible for new or dissident journals to succeed in the race for reputation. Publishing in top-ranked journals, however, is crucial for the individual careers of researchers and the reputation and financing of whole economics departments (see Lee 2008b). ${ }^{24}$ How fatal this is for the reputation of "dissident" or heterodox economists is best demonstrated by a quick look at the top ten nonmainstream journals ${ }^{25}$ among Thomson Scientifics' Social Science Citation Index (SSCI) ${ }^{26}$

Based on data from the Journal Citation Reports (JCR), Table 1 shows only two heterodox journals within the top fifty and eight within the top hundred, illustrating the marginal role heterodox economic journals play in quantitative research analysis.

Table 1. Top Ten Heterodox Journals in Thomson's Social Sciences Citation Index (based on data from Journal Citation Reports - Social Sciences Edition 2007)

$\mathrm{Nr}$. in

Nr. JCR 2007 Heterodox Journal

Impact Factor

\begin{tabular}{ccll}
\hline 1 & 17 & Economy and Society & 1.678 \\
2 & 23 & Ecological Economics & 1.549 \\
3 & 51 & Work, Employment and Society & 1.051 \\
4 & 56 & Review of International Political Economy & 1.000 \\
5 & 78 & Journal of Economic Behavior and Organization & 0.772 \\
6 & 90 & New Political Economy & 0.702 \\
7 & 91 & Cambridge Journal of Economics & 0.700 \\
8 & 93 & Journal of Development Studies & 0.686 \\
9 & 107 & Journal of Evolutionary Economics & 0.562 \\
10 & 113 & Feminist Economics & 0.541 \\
\hline \hline
\end{tabular}


Several empirical indicators underline the first impression that the logics of citation ranking and citation praxis in top journals mutually reinforce each other. If we add the top ten mainstream journals of Thomson's index in 2007 (see Table 2) to our sample of top ten heterodox journals and compare citation data we find three noteworthy points. First, we come to the (trivial) conclusion that a higher amount of orthodox cites in a certain article or journal increases the probability of being cited by others (and therefore enlarges the impact factor), while a higher amount of heterodox cites decreases this probability. Since the top ten mainstream journals are the top ten journals in the SSCI economics category this is not really surprising and only mirrors the low impact factor of the top ten heterodox journals as illustrated by a simple regression model (see Table 3).

\section{Table 2. Top Ten (Orthodox) Journals in Thomson Scientific's Social Sciences Citation Index (based on data from Journal Citation Reports - Social Sciences Edition 2007)}

\begin{tabular}{rlc}
\hline \hline Nr. & Orthodox Journal & Impact Factor \\
\hline 1 Journal of Political Economy & 4.190 \\
2 Journal of Economic Literature & 3.973 \\
3 Quarterly Journal of Economics & 3.688 \\
4 Journal of Accounting and Economics & 3.034 \\
5 Journal of Financial Economics & 2.988 \\
6 Econometrica & 2.972 \\
7 Journal of Economic Perspectives & 2.831 \\
8 Journal of Economic Geography & 2.679 \\
9 Review of Economic Studies & 2.539 \\
10 Journal of Economic Growth & 2.292 \\
\hline \hline
\end{tabular}

Second and more interesting is a calculation regarding the interaction of orthodoxy and heterodoxy in terms of citations to articles published between 1989 and 2008. We compare the number of citations in the top ten orthodox journals coming from the top ten heterodox journals and vice versa. By arranging our data this way we can ask whether one of the two factions "receives" more citations than it "passes down" to the other camp. From another point of view this could be interpreted as a measure of "openness" of the two camps.

Table 4 shows that the top ten heterodox journals cite the top ten orthodox journals roughly eleven times more often than vice versa. This goes in line with our general argument. The journals at the top are those, which we - as economists - have to refer to, even if we disagree. The logic of citation metrics leads to the paradox 
Table 3. Impact of Orthodox and Heterodox Citations on a Journal's Impact Factor (based on data from Thomson Scientific - Web of Science 01-2009 for 1989-2008)

\begin{tabular}{|c|c|c|c|c|}
\hline & coefficient & $\begin{array}{l}\text { standard } \\
\text { error }\end{array}$ & t-statistic & p-value \\
\hline $\begin{array}{l}\text { Nurnber of } \\
\text { orthodox citations } \\
1989-2008\end{array}$ & 0.00095 & 0.00063 & -2.043 & $0.0568^{*}$ \\
\hline $\begin{array}{l}\text { Number of } \\
\text { heterodox citations } \\
1989-2008\end{array}$ & -0.00128 & 0.0003 & 3.152 & $0.0058^{* * *}$ \\
\hline Intercept & 1.51186 & 0.37726 & 4.007 & 0.0009 \\
\hline
\end{tabular}

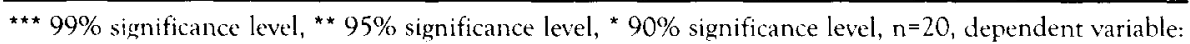
impact factor; method: ordinary least squares, adjusted $R^{2}=0.43$

Table 4. Citation-Transfer between (Top-Ten) Orthodoxy and Heterodoxy (based on data from Thomson Scientific - Web of Science 01-2009 for 1989 2008)

\begin{tabular}{|c|c|c|c|c|}
\hline $\begin{array}{l}\text { Top ten heterodox } \\
\text { journals }\end{array}$ & $\begin{array}{l}\text { Citations in } \\
\text { top ten } \\
\text { orthodox } \\
\text { (export) }\end{array}$ & $\begin{array}{l}\text { Citations of } \\
\text { top ten } \\
\text { orthodox } \\
\text { (import) }\end{array}$ & Difference & $\begin{array}{c}\text { Propor } \\
\text { tional } \\
\text { Factor }\end{array}$ \\
\hline Economy and Society & 16 & 49 & -33 & 3.06 \\
\hline Ecological Economics & 10 & 681 & -671 & 68.10 \\
\hline $\begin{array}{l}\text { Work, Employment and } \\
\text { Society }\end{array}$ & 5 & 29 & .24 & 5.80 \\
\hline $\begin{array}{l}\text { Review of Initemational } \\
\text { Political Economy }\end{array}$ & 26 & 70 & -44 & 2.69 \\
\hline $\begin{array}{l}\text { Journal of Economic Behavior } \\
\text { and Organization }\end{array}$ & 201 & 1884 & -1683 & 9.37 \\
\hline New Political Economy & 1 & 38 & -37 & 38.00 \\
\hline $\begin{array}{l}\text { Cambridge Journal of } \\
\text { Economics }\end{array}$ & 47 & 463 & -416 & 9.85 \\
\hline $\begin{array}{l}\text { Journal of Development } \\
\text { Studies }\end{array}$ & 43 & 487 & -444 & 11.33 \\
\hline $\begin{array}{l}\text { Journal of Evolutionary } \\
\text { Economics }\end{array}$ & 31 & 395 & .364 & 12.74 \\
\hline Feminist Economics & 5 & 133 & -128 & 26.60 \\
\hline Total & 385 & 4229 & .3844 & 10.98 \\
\hline
\end{tabular}


consequence that citing a mainstream journal to criticize the dominant paradigm strengthens its position in quantitative "quality" measures. In this context, heterodoxy not only refers much more to orthodox research and is thus more open for it, but also strengthens the orthodox position in the common institutional research environment via citation metrics. Looking at individual journals, the huge differences between heterodox journals cannot be explained simply by reciprocity: citing many orthodox articles does not lead to being cited more often by mainstream journals than citing a few orthodox articles and vice versa.

One main factor further driving this development and contributing to the mutual success of citation ranking and neoclassical economics is obviously that the orthodox journals form a tight network - much tighter than that of their heterodox counterparts. In terms of network-benefits the often scattered and isolated strands of heterodoxy are simply no match to the tight and prestigious "core-network" of today's orthodoxy.

The statistics in Table 5 demonstrate that in our sample nearly two of three citations in the top ten mainstream journals come from another one of the top ten mainstream journals, when correcting for self-citations. In the heterodox community this practice is much less common - only every fifth citation resides in the heteiodox "network." Aside from the obvious divide between orthodoxy and heterodoxy, the neoclassical community's network is much more effective - at least in terms of Thomson's Impact Factor.

Table 5. Relative Relevance of the Respective Network Affiliation for Citation Collecting (based on data from Thomson Scientific - Web of Science 012009 for 1989-2008)

\begin{tabular}{|c|c|c|c|}
\hline & $\begin{array}{c}\text { Average } \\
\text { percentage of } \\
\text { citations from top } \\
\text { ten heterodox } \\
\text { journals }\end{array}$ & $\begin{array}{c}\text { Average } \\
\text { percentage of } \\
\text { citations from top } \\
\text { ten orthodox } \\
\text { journals }\end{array}$ & $\begin{array}{l}\text { Average percentage of } \\
\text { intra-network } \\
\text { (heterodox/orthodox) } \\
\text { citations excluding self } \\
\text { citations }\end{array}$ \\
\hline $\begin{array}{l}\text { in top ten } \\
\text { heterodox }\end{array}$ & $\begin{array}{c}60.35 \% \\
\text { (intra-network) }\end{array}$ & $\begin{array}{c}39.65 \% \\
\text { (inter-network) }\end{array}$ & $\begin{array}{c}19.3 \% \\
\text { (intra-network) }\end{array}$ \\
\hline $\begin{array}{l}\text { in top ten } \\
\text { orthodox }\end{array}$ & $\begin{array}{c}4.89 \% \\
\text { (inter-network) }\end{array}$ & $\begin{array}{c}95.11 \% \\
\text { (intra-network) }\end{array}$ & $\begin{array}{c}64.22 \% \\
\text { (intra network) }\end{array}$ \\
\hline
\end{tabular}


Because of the self-reproducing and self-reinforcing logic of contemporary journal rankings, the editors and reviewers of these so-called "top journals" are able to define not only what are "good" and "bad" pieces of work in economics but also, and foremost, what in general should be considered as an "economics" paper. It is this institutional logic of citation rankings that leads to an oligopoly on interpretation by a few editorial boards and makes the amplifier we describe in the subsequent section so powerful: to close your borders.

\section{Amplifier \#2: Close your borders}

One of the most important abilities of the proponents of neoclassical economics is their power to define the borders of Economics as a discipline. Very often, the narrow view of neoclassical economics is the main criterion for deciding what kind of argument or research does or does not qualify as economics. In this sense, heterodox schools, qualitative methodology, and socio-economic approaches are repeatedly excluded from the "economic community" and labeled as "sociology," "not representative" or "esoteric" - independent of their dealing with clearly economic subjects: "One of the privileges bestowed upon those who adhere the conventional paradigm is that they are not required to defend the very foundation of their analysis" (Whalen 1987, 260).

It is no surprise that such behavior can be observed, especially when neoclassical theorists encounter their critics: Samuelson once denied John K. Galbraith his profession as an economist. The Journal of Political Economy rejected Joan Robinson's contribution on the capital controversy and proposed her to submit it to "a journal for the amateur intellectual or to an obscure journal whose readers would not have heard of the Cambridge controversies" (Lee 2004, 749). The students who stood at the beginning of the post-autistic-economics movement were attacked as bad mathematicians (see Solow 2001). This shows a tendency to use the "power of definition" regarding economics to quiet critical voices by condemning them as untrustworthy, or at least not really noteworthy, because of a lack of "appropriate" professional skills and methods. "Thus, in explaining to a stranger, for example, why he holds the Sociollogist]s or the Pollitical] scilientis]s in such low regard, the Econ [omist] will say that 'they do not make models' and leave it at that" (Leijonhufvud 1973, 330).

Another example for the consequences of this narrow theoretical boundary of economics is the difficulty of bringing interdisciplinary concepts or aspects into the economic debate. Because of "the exclusivism and exclusionism which they practice ... hy equating economics with neoclassicism" (Samuels 2000, 306), the attitude toward such contributions ranges from skepticism to open hostility. Interdisciplinary research is not really "worth its opportunity costs, because you can publish it nowhere," as a member of the economics department at the University of Linz once put it.

One aspect of this behavior is obviously to identify economics as a subject not by the issues covered but via a specific and narrow methodological approach, which 
marks the end of economic territory. This perspective is compatible with the so-called "economic imperialism" (Lazear 2000), which applies this "narrow methodological approach" on traditionally non-economic problems, thereby transforming them into economic problems, i.e., new research puzzles for the dominant paradigm. In this sense, a main strategy of closing the ranks is not to restrict the applicability of economic thinking but to control which people and which kind of arguments are accepted inside the economic discourse and whose contributions - be it regarding theory or policy - have to wait outside the doors.

\section{Mechanism \#3: Learning Effects}

Normally, learning effects are attributed to the consumers' side of the world, meaning that the implementation of a new technology leads to (costly) learning by the users of this technology; therefore, switching to a different technology has to meet some incentive-based hindrances (David 1985). However, we argue that learning effects play a role on both - supply and demand - sides. On the supply side, a more or less unchanging and logically consistent body of knowledge, together with a standard set of methods, which are to be used in order to fulfill the requirements of "ceremonial adequacy" (Veblen 1898, 382), reveal a clear-cut piece of knowledge. This is established as a standard criterion, showing what knowledge and skills are necessary in order to be accepted as a member of the economic community.

This is certainly a(n) (strategic) advantage compared to other social sciences where the lack of an obligatory set of theoretical and empirical propositions leads to a lower social cohesion within the discipline. One can understand these facts also as a part of coordinating processes, but this is mostly a question of labeling and the empirical overlapping of analytically separated mechanisms of path dependence. Although there is a methodological and theoretical standard becoming more powerful and established with every additional user (direct network effect), the success of this standard still seems to be favored by the fact that it is easy to identify which rules are to be adopted and which methods and theories are to be learned-by-heart.

This standard set of axioms and methods - and the whole complex of neoclassical economic theory built upon it - can be understood as a kind of "asset specificity" (Williamson 1985). The past intellectual investment in neoclassical economics is not to be wasted or narrowed by abandoning or criticizing it. In this sense, the ordinary scientist "defends his assets, mostly consisting of knowledge drummed into the economist's head during his graduate studies and repeated in slight modifications till retirement" (Peukert 2006, 45; translation by the authors).

These theoretical standards are sometimes also referred to as a kind of "labor saving device" and thus represent the classical meaning of learning effects. Once absorbed, the standard requirements of ceremonial adequacy are fulfilled, and updating them is easier than doing something completely new (like learning how to use a new set of methods, for example). In any case, the aspiration to learn the necessary rules as quickly and as well as possible is an obligatory precondition in order to be a part of the economic community. 'The young Econ[omist], or 'grad,' is not 
admitted to adulthood until he has made a 'model' exhibiting a degree of workmanship acceptable to the elders of the 'dept' in which he serves his apprenticeship" (Leijonhufvud 1973, 329).

From this point of view it is interesting to note that in the German-speaking countries the assertion that "neoclassical economics is important when solving problems in economic policy" finds disproportionally high agreement among younger economists (Frey, Humbert and Schneider 2007, 362). This point is a critical one. If, in the context of a scientific process, "adaptiveness" to given structures is too well established - and reinforced through the mechanisms of the journal evaluation process already mentioned - this may lead to a noncritical research culture, where people end up "doing their things well without knowing (on a meta-level) what they are doing anyway." And, the paradigm reproduces itself through the interplay between scientific prestige and reputation, prospects for personal growth, institutionalized citation oligopolies and the ambition of the young researcher. "If the majority of economists are orthodox neoclassical theorists, then, in order to obtain prestige or, even, for the young, relatively unknown economist, any kind of academic position at all, the wisest strategy may be to be a neoclassical economist too and carry out research along similar lines" (Earl 1983, 95).

On the "demand side," an intuitively plausible "light" version of modern neoclassical theory is available (like that presented in Mankiw 2001), which is nonformal, easy to grasp, and delivered to a large audience (for example, to the huge number of students studying economical sciences and business administration). The metaphorical pictures implied by this trivial or simple version of neoclassical theory often have a strong ideological taint toward free market policies (Ötsch 2008). Nonetheless, they are widely used to educate pupils, laymen, politicians, and university students, and are easy to follow in practice ${ }^{27}$ if some basic principles (utility/profit maximization, equilibrium, shape of supply and demand, paretoefficiency) are understood by the audience.

\section{Amplifier \#3: Assimilate your enemies}

Every available heterodox branch of economic theory has its own quarrelsome relation to neoclassical economics. Many of them have certain theoretical strengths, which make them superior to neoclassical standard theory in some aspects. Evolutionary Economics, for example, claims to be superior in describing the processes underlying economic change. The innovative starting point of these heterodox theories is most times a certain aspect of life that had not yet been in the focus of neoclassical economics. For ecological economics, this unique startmng point or, more economically, this unique selling proposition is its focus on the environment, while feminist economics is interested in gender-specific relations, and so on.

The neoclassical economic community has accepted the contributions of these schools insofar as they use the new and innovative starting points and try to implement them in their own research. In this sense, Pigou's classical "external 
effects" have been revitalized as a foundation of environmental economics, the concepts of utility maximization and public choice have been adapted to the analysis of institutions (neo-institutionalism vs. institutionalism), and the economic analysis of discrimination (Becker 1971) stood in an exemplary way for the economic view on gender-relations. In other words: some aspects of heterodox economists' ideas have entered the mainstream - and others have not.

Looking at evolutionary economics as an example, it is interesting that one of its main antecedents can still be found on the citation lists of neoclassical economists: Joseph Schumpeter is actually quite popular when looking at recent developments in the neoclassical theory of growth and cycles (Barro and Sala-i-Martin 2004; Helpman and Trajtenberg 1994; Aghion 1998). But the intellectual role of Schumpeter in this context is often reduced to a theoretical figure to review the importance of "creative destruction," which is used as a justification for the introduction of spontaneous technology jumps or simple diffusion processes. These are to describe the transition phase between the usual equilibria. ${ }^{28}$ Moreover, most of these contributions do not address the question of why the economy changes, but are only interested in quantitative descriptions of the way from one equilibrium to another.

In this sense, the references to Schumpeter in neoclassical growth theory seem somehow contradictory to the main insights of Schumpeterian economics, namely, that there is no such thing as equilibrium, and change therefore is not the transition between two equilibria, but the essence of economic activity itself. "Therefore, it follows that there is no dynamic equilibrium. . . . Development and Equilibrium, both understood in our sense, are therefore antagonistic and cancelling each other out" (Schumpeter [1912] 2006, 482; translation by the authors).

These short examples reveal a tendency of neoclassical economics to assimilate only those parts of a theoretical alternative that are more or less compatible with the existing body of neoclassical theory. This is a finding that also holds for the case of Keynesian economics, which was considered as a substantial threat by neoclassical economists especially through its short-term political and paradigmatical dominance in the post-war period until the 1970s. Therefore, it seems reasonable that "the shift towards market solutions did not occur spontaneously; it was actively promoted by groups of economists committed to opposing socialism making the case for free enterprise, and reviving the fortunes of liberalism" (Backhouse 2005, 365-366; see also Plehwe 2007). In more detail, Fulbrook puts it as follows:

Keynes, a mathematician turned economist, had said some rude things about mathematical economists. Shocked by the way they abused mathematics, especially when they applied them in meaningless ways to unsuitable phenomena, he made no secret of his professional contempt for their empty pretentiousness. But these economists were soon to have their revenge. Led by Paul Samuelson in the US and John Hicks in the UK, they set about mathematicising Keynes's theory. Or, more accurately, a part of his theory. They left out all those bits that were inconsistent with the neoclassical axioms. Their end product was a formalised version of Keynes 
that is like a Henry Miller novel without sex and profanity. (Fulbrook 2007, 165)

And indeed, in 1937, only one year after the release of Keynes' General Theory, John Hicks published a so-called "book review" of the General Theory in which he developed the famous IS-LM-diagram that is still heavily used today in short-run macroeconomics, ${ }^{29}$ and claimed to sum up the Keynesian theory as a part of the traditional neoclassical framework. Nevertheless, he withheld central cornerstones of the Keynesian theory like imperfect markets, the liquidity preference, expectations, and the role of uncertainty. Nonetheless, the Hicksian version of "Keynesian" theory, which later merged into neoclassical synthesis and New Keynesian economics, became the dominant and popular interpretation of Keynes' contribution, leaving important parts of the original Keynesian theory aside. "Keynes without uncertainty is something like Hamlet without the prince" (Minsky [1975] 2008, 55).

Perhaps this proposition could be modified with respect to Schumpeter in a way to express that "Schumpeter without history is rather like Keynes without uncertainty" in order to get a clear picture what the common notion between the two examples is. Neoclassical economics assimilates some central, but plain to integrate, building blocks of competing theories, and afterwards claims that work on the relevant areas of research is already in progress and that the new theoretical alternative is therefore not so new anyway. "With this revision Mr. Keynes takes a big step back to Marshallian orthodoxy and his theory becomes hard to distinguish from the revised and qualified Marshallian theories, which, as we have seen, are not new. Is there really a difference between them or is the whole thing a sham fight?" (Hicks 1937, 153).

This observation indicates that there is a certain framework to partially assimilate competing theories in order to secure hegemonial power. Whether this strategy is the result of a conscious regime or just a more or less normal development in the case of paradigmatical dominance cannot be answered here. Taking into account the variety of characters working in the academic field of economics, it seems most reasonable that - depending on the case - both reasons can turn out to be true. But conscious or not, assimilation is clearly a major strategy in order to close the ranks and to a priori prevent path-breaking behavior.

\section{Conclusions and Remarks}

So far we have seen the following:

a) The theory of path dependence in general explains Kuhnian paradigmatical dominance as a theoretical lock-in resulting out of distinct positive feedback mechanisms within a particular field of research.

b) Economics is locked into neoclassical thinking, which prevents the emergence of possible alternatives regardless of their qualities and strengths. This is the main reason for the parochial and non-pluralistic nature of economics seen from the perspective of the philosophy of science. 
c) The paradigmatical lock-in goes along with the effects known from the application of path dependence theory in non-technological contexts and is reinforced by additional hegemonial strategies. In particular, the emergence of citation metrics as an "objective" quality measure constitutes a "critical juncture" (Mahoney 2000, 526), as it institutionalized and reinforced the paradigmatical dominance already in place. This, by the way, nicely illustrates that there are noteworthy similarities between the concepts of path dependence in economics, hegemony in political science, and paradigm in philosophy of science (see also: Sterman and Wittenberg 1999).

From a heterodox perspective, these conclusions lead to another question: If the non-pluralistic character of economics is at least partly caused by mechanisms of path dependence, what can be done in order to break this theoretical lock-in?

In this context Sydow, Schreyögg and Koch $(2005,22-24)$ review different types of potentially path-breaking strategies:

a) Discursive strategies try to overcome blind spots resulting from a deficit of reflexive discourse on a cognitive level by "surfacing hidden self-reinforcing patterns in organizational settings [and] the reflection of these patterns."

b) Behavioral strategies try to overcome unconscious routines, like traditional working methods, rules, and organization guidelines.

c) Systemic approaches try to focus on reproduction logics of social systems that may be enacted by the system's members without them being conscious of it.

All of these theoretical approaches highlight different areas in economic research. Taking discursive strategies as a starting point, it seems obvious that there are a lot of blind spots concerning the scientific quality of economics, something which could be a possible cornerstone of a critical reflection on standard neoclassical theory. In addition to the already mentioned flaws in standard economic theory, there are blind spots concerning the questionable epistemological grounding (see: Vaihinger [1911] 1986; Friedman [1953] 1966), the absence of qualitative methods and arguments, and the monopoly position of only one dominating theory. Therefore, it seems fruitful for heterodox economic schools to engage in highlighting these blind spots in all possible contexts (publications, lectures, congresses and meetings, student's publications, thesis offers, public speeches and articles . . .). As a precondition for scientific progress, this would also be necessary to encourage students, laypeople and professionals to reflect their own points of view and hence prepare the ground for unlocking economic theory from neoclassical thinking. Another aspect of the discursive sphere could lead to the recommendation of being more concerned with matters actually relevant for political application. If heterodox economists tackle problems highly relevant in the political discourse this might be a "back-door option" to enter the economic debate.

Methodological discourse provides astonishing examples for the unwritten rules applied in economics when it comes to reflexive discussions and debates. "As a rule, it is bad to spend time on 'methodological' and broad-stroke issues rather than the nittygritty of the phenomena being studied" (Rabin 2002, 6).

From a behavioral point of view, two main "behavioral rules" seem to be main hindrances for path-breaking activities in economics. First, there is at least some 
evidence that the economic departments follow the rules of their elder members. "In the more important villages, furthermore, ... the young adult must continue to demonstrate his ability at manufacturing these artifacts [i.e. economic models]. If he fails to do so, he is turned out of the 'dept' to perish in the wilderness" (Leijonhufvud 1973, 330).

Second and more important is the obvious notion of economists, established as a rule often referred to as the "economic method," to use more or less the same method regardless of the subject of research. "Rather than starting with a question about an aspect of social reality and determining an appropriate method, modern economists usually start with a particular type of method and presume, mistakenly, that it must be appropriate to all social contexts" (Lawson 2004, 22).

This indicates that a precondition, or at least a side effect, of unlocking economics from neoclassical thinking is a change in the methodological rules that are to be fulfilled in order to be a member of the economic community. Furthermore, a broadening of methods probably would also favor heterodox theories that use different mathematical and non-mathematical approaches to similar research problems. It seems reasonable to say that if the methods are more diversified, the theories might follow more easily. If interesting problems or results of heterodox economists fail to fulfill the mainstreams' narrow methodological conceptions it might be worth a try to forge alliances with related, but methodologically more open disciplines in order to induce a broader debate within the social sciences.

Recommendations for the citation practice of individual heterodox researchers, who do not want to strengthen the institutional position of orthodox journals by criticizing them, might include tactics like citing working paper versions of orthodox articles or abstaining from redundant orthodox citations. Lee $(2008 \mathrm{~b}, 247)$ suggests editors of heterodox journals increasing "their domestic production of citations, import citations and the number of heterodox journals from which they come." Of course, focusing on (the biases of) common citation metrics cannot compensate for lack of research quality and should not receive disproportionate attention by heterodox scholars.

Finally, the systemic approach reflects of the importance of the autopoietic attributes of social systems and thus hints at some details important for those strands of economics, which hold their position "in between" the neoclassical paradigm and the heterodox schools seeking compromises and quarrels with the dominating paradigm. Examples for such programs are experimental and evolutionary economics. As a result, it is often not easy to say where to attribute the contributions of, for example, evolutionary economics in terms of a hegemonial struggle or pathorientation. This paradigmatical attribution is not based on academic reasoning, but is mainly a question of perception. Similarly, contributions falsifying neoclassical propositions from experimental economics are perceived as further attributions to the subsequently growing body of neoclassical theory, showing once again its predictive power in all kinds of scientific fields - sometimes especially because of the authors' efforts to relate their findings to the dominant paradigm (ct. Rabin 2002; Fehr and Gächter 2000). 
This attribution problem is a crucial point when discussing paradigmatical dominance: If we perceive the insights of evolutionary or experimental economists as enrichments of neoclassical theory, then these results are interpreted as "solved puzzles" by mainstream economics instead of being understood as the anomalies and falsifications they substantially are. It is quite obvious and follows the usual reasoning (Kuhn [1962] 1996; Sterman and Wittenberg 1999) that the strength of a dominating paradigm depends on the relation between solved puzzles and unsolved ones (anomalies). In this sense, "enriching" neoclassical theory with additional research fields and theoretical improvement also necessarily strengthens neoclassical economics' position in terms of hegemonial struggle. From a strategic point of view, it therefore seems shortsighted to try to "preserve most of the discipline's significant achievements to date" (Nelson and Winter [1982] 1996, 6) and to enrich neoclassical theory with notions from evolutionary or behavioral economics.

If we accept the Kuhnian proposition that the existence of a competing paradigm is a precondition for the withdrawal of a dominating scientific paradigm, another strategic question arises: Should heterodox economists present their own theories as paradigmatical alternatives to neoclassical economics in the sense of a "competing paradigm," or should they join in the common pleas for a methodological and theoretical pluralism in economics (see Van Bouwel 2005 or King 2004)?

Formal models based on Kuhn's theory of scientific revolutions (as in Sterman and Wittenberg 1999) lead to the result that the number of competing paradigms (in relation to the dominant one) is a decisive factor - much more decisive than, for example, the intrinsic explanatory capability (quality) of a paradigm - for (1) whether the dominant paradigm will sustain and (2) what will happen to the competing paradigms. The general result is that the higher the number of competitors, the lower the probability of a paradigm-shift and the higher the probability that potential competitors will perish along the way and only be remembered as foolish errors of the past.

Therefore, the idea of theoretical pluralism provides - due to the integration of the strengths of various schools of thoughts and disciplines (see O'Hara 2007 as an example) - the strategic advantage of a unified paradigmatical alternative. Instead of unavailingly and in parallel struggling for paradigmatic dominance, a joint effort for a pluralist (meta-)paradigm - in the sense of multiple paradigms competing on a similar level - seems much more promising. This pluralist paradigm not only has the benefit of being a unique competitor, but also cumulates the "puzzles solved" by the different schools of thought available in the heterodox network, strengthening its position in the struggle of paradigms. Furthermore, it seems possible to design (more) curricula, journals, textbooks or doctoral programs integrating diverse heterodox strands of thought in a common institutional body. These considerations and suggestions indicate that "paradigmatical dominance" in the Kuhnian sense is not the inevitable fate of scientific enterprise, but a result of social interactions. And since paradigmatical dominance is a social phenomenon, we can escape this dilemma by deconstructing our social reality and consequently insist on and advocate for theoretical and methodical pluralism as the central guideline in economic research. 


\section{Notes}

1. See Lee and Keen (2004) for an overview of more than 70 different economic textbooks.

2. In fact Kuhn himself was not very precise with this and used "paradigm" in several different meanings - Masterman $(1970,61)$ lists 21 different meanings associated with the term in Kuhn's structure of scientific revolutions.

3. The metaphor of the machine is in principle a dynamic concept, since there is the tendency to use the most recent type of machine as a metaphorical substitute for its predecessors. Consequently, the computer-metaphor has experienced a rise in recent economics leading to the interpretation of "economics as a cyborg-science" (Mirowski 2008).

4. Colander, Holt and Rosser $(2004,493)$ mention Paul Samuelson, Kenneth Arrow, Roberr Solow, Thomas Schelling, Amartya Sen, Joseph Stiglitz, Chris Sims, Michael Woodford, George Akerlof, Richard Thaler, Anne Krueger, and Jagdish Bhagwati.

5. In detail, evolutionary game theory (1), ecological economics (2), psychological (3) and experimental (4) conomics, computer simulations (5) and complexity theory (6) are regarded as "new and challenging" research programs (Colander, Holt and Rosser 2004, 496). While the arrival of (1), (2) and (6) in mainstream economics can be questioned, (3) and (4) are effectively extending the borders of neoclassical economics and can be understood as variants of axiomatic variation.

6. In fart, Colander, Holt and Rosser (2004) refer to research "at the edge of the mainstream" for illustrating their view of the new research programs addressed above, while this assessment is interested more "in the center of the mainstream."

7. Of course, there are some "partial solutions" dealing with specific problems in the neoclassical framework. These solutions somehow extend the scope of the neoclassical paradigm (e.g., by interpreting altruism as a source of utility and therefore "explaining" altruism in an economic framcwork), but these results only seldomly enter the neoclassiocal "ideal of conduct."

8. A concept famously defended by Milton Friedman ([1953] 1966).

9. The concept of the "representative firm" was introduced by Marshall to argue that markets reach a situation of equlibrium in the long-run, whereas in the short run "the positive functions of competition were not defined by Marshall in terms of efficient allocation (. .). but rather in terms of the stimulus competition gives to the discovery of improved methods of production" (Screpanti and Zamagni 1995, 180). Therefore the concept of the representative firm had an evolutionary notion; an element making coonomic theories "heretic" till today.

10. For a detailed study on the MPS, see Walpen (2004).

11. The already mentioned Anthony Fisher played an important role here. Compare Cocketr (1995) and Walpen (2004).

12. Walpen $(2004,399-400)$ counts over 100 sister organizations, which are part of the MPS-network and share its political motives, like the Institute of Economic Affairs, the Heritage Foundation and the Cato Institute.

13. In this sense Paul Samuelson, for example, was not a member of the MPS, but a very important person for and within its related networks.

14. We thank one of the anonymous reviewers for this interesting example.

15. In this "history," Backhouse focuses on new academic institutions such as the MMF or the World Bank and their influence on Economics.

16. Sec Dobusch and Schüßler (2007) for a differentiation herween the use of "parh" and "path dependence" as a mere metaphor and as a theoretical approach in the tradition of David (1985) and Arthur (1989).

17. Sometimes mimetic herd behavior (Bannerjee 1992) is also referred to as "learning" in the context of path dependence theory (e.g., Ackermann 2001; Denzau and North 1994). This is a case that we do not emphasize in our definition of "learning effects."

18. As the term "amplifier" sugyests, we focus on strategic actions that interact with mechanisms reinforcing the dominant paradigm and consider (potential) "dampers" only in our final outlook.

19. Frey, Humbert and Schneider (2007) find similar evidence for the German-speaking countries.

20. In fact it took the Kopernikean approach more than hundred years to catch up.

21. Named after St. Matthew's famous quote: "For unto every one that hath shall be given, and he shall have abundance; but from him that hath not shall be taken away even that which he hath." 
22. For example, Merton mentions that nobel laureates sometimes even refuse to coauthor a paper reporting research on which they have collaborated in order not to diminish the recognition accorded their less-well-known associates.

23. The big eight include the Universities of California Berkeley, Harvard, Stanford, Yale, Chicago, Columbia, Princeton and MIT.

24. The most prominent example in recent history has certainly been the splitting of the Economics department at the University of Notre Dame that did not want to publish in so-called "top journals." As one of the professors involved reports, the decision to split the department was explicitly justified with reference to a ranking logic: "They wanted a more highly ranked economics department as part of a more highly ranked university" (Hayes 2007).

25. "Dissident" or non-mainstream journals are identified by their appearance in Frederic Lee's "Informational Directory for Heterodox Economists" (Lee 2009).

26. As demonstrated by Lee (2008a) using the SSCI as an index partially discriminates against heterodox journals, since many of these journals are not even listed within the SSCI. This discrimination primarily results in a lower Impact-Factor for those heterodox journals included in the SSCI, but as the Impact Factor is not our primary focus we do not consider this to be a major problem. Since we choose "ten of every branch" and analyze them relative to each other, we have leveled out some other biases associated with SSCI-data (e.g., heterodox citation networks, which are underestimated by using SSCI in an overall comparison). The data we used for our tables is availahle at http:// www.dobusch.net/pub/uni/citation-data.xls.

27. Actually, "profit maximization" is anything but easy even to aim at in practice. Most practitioners however, think of thernselves as "profit maximizers" when following neoclassical imperatives.

28. Even more, many scholars (e.g., Langlois and Everett 1994) attribute to Schumpeter the theoretical concept of a "punctuated equilibrium" - a concept Schumpeter probably would have rejected strongly, as a look at his fundamental criticism of any equilibrium approach of growth dynamics shows (Schumpeter [1934] 1983).

29. But was never used by Keynes himself.

\section{References}

Ackermann, Rolf. Pfadabhängigkeit, Institutionen und Regelreform. Tübingen: Mohr Siebeck, 2001.

Albert, Hans. "Modellplatonismus. Der neoklassische Stil ökonomischen Denkens in kritischer Beleuchtung." In Logik der Sozialwissenschaften, edited by Ernst Topitsch, pp. 406-434. Berlin: Kiepenheuer \& Witsch, [1963] 1971.

Aghion, Philippe and Peter W. Howitt. Endogenous Growth Theory. New York: MIT Press, 1998.

Arrow, Kenneth J. and Gerard Debreu. "Existence of Equilibrium for a Competitive Economy." Econometrica 22 (1954): 265-290.

Arrow, Kenneth J. "Path Dependence and Competitive Equilibrium." In History Matters. Essays on Economic Growth, Technology, and Demographic Change, edited by William A. Sundstrom, Timothy W. Guinnane and Warren C. Whatley, pp. 23-35. Stanford: Stanford University Press, 2003.

Arthur, Brian W. "Competing Technologies, Increasing Returns, and Lock-in by Historical Events." The Economic Journal 99 (1989): 116-131

"Increasing Returns and the New World of Business." Harvard Business Review July-August, (1996): 100-109.

Ayres, C. E. "Veblen's Theory of Instincts Reconsidered." In Thorstein Veblen: A Critical Reappraisal, edited by Douglas F. Dowd, pp. 25-37. Ithaca: Cornell University Press, 1958.

Backhouse, Roger E. "Progress in Heterodox Economics." Journal of the History of Economic Thought 22, 2 (2000): $149-155$

"The Rise of Free Market Economics: Economists and the Role of the State since 1970." History of Political Economy 37 (2005): 355-392.

Banerjee, Victor A. "A Simple Model of Herd Behavior." The Quarterly Journal of Economics 107, 3 (1992): $797-816$

Barro, Robert J. and Xavier Sala-i-Martin. Economic Growth. New York: The MIT Press, 2004.

Becker, Gary S. The Economics of Discrimination. Chicago: Chicago Universiry Press, 1971. 
Bedeian, Arthur G. "The Manuscript Review Process: The Proper Roles of Authors, Referees, and Editors." Journal of Management Inquiry 12 (2003): 331-338.

Blanchard, Olivier. Macroeconomics, $2^{\text {nd }}$ Edition. Englewood Cliffs: Prentice-Hall, 1999.

Breyer, Friedrich. "Die Chancen der Sozialen Marktwirtschaft und die Rolle der Ökonomen." Perspektiven der Wirtschaftspolitik 9, 2 (2008): 125-138.

Chalmers, Alan F. Wege der Wissenschaft. Berlin: Springer, 1989.

Cockett, Richard. Thinking the Unthinkable. Think-Tanks and the Economic Counter-Revolution 1931-1983. London: Harper Collins, 1995.

Colander, David. "The Death of Neoclassical Economics." Journal of the History of Economic Thought 22, 2 (2000): 128-143.

Colander, David, Richard P.F. Holt and John B. Rosser, Jr. "The Changing Face of Mainstream Economics." Review of Political Economy 16, 4 (2004): 485-499.

David, Paul. "Clio and the Economics of QUERTY." American Economic Review 75 (1985): 332-337.

. "Path Dependence, Its Critics, and the Quest for 'Historical Economics'." In Evolution and Path Dependence in Economic ldeas: Past and Present, edited by Pierre Garrouste and Stavros Ionnides, pp. 15. 40. Cheltenham: Edward Elgar Publishing, 2001.

Davis, William L. "Economists' Opinion of Economists' Work." American Journal for Economics and Sociology 66, 2 (2007): 267-288.

Denzau, Arthur T. and Douglass C. North. "Shared Mental Models: Ideologies and Institutions." Kyklos 47, I (1994): 3-31.

Dobusch, Leonhard and Elke Schüßler. "From Storytelling to Theory: Unlocking Path Dependency from Metaphorical Usage." Paper presented at the 23rd EGOS Colloquium, July 5-7, 2007, Vienna.

Dosi, Giovanni. "Technological Paradigms and Technological Trajectories: A Suggested Interpretation of the Determinants and Directions of Technical Change." Research Policy 11, 3 (1982): 147-162.

Dow, Sheila C. "Prospects for the Progress of Heterodox Economics." Journal of the History of Economic Thought 22, 2 (2000): 157-170.

Earl, Peter E. "A Behavioral Theory of Economists' Behavior." In Why Economics is Not Yet a Science, edited by Alfred S. Eichner, pp. 90-125. London: MacMillan, 1983.

Fehr, Ernst and Simon Gächter. "Fairness and Retaliation: The Economics of Reciprocity." Journal of Economic Perspectives 14 (2000): 159-181.

Friedman, Milton. Essays in Positive Economics. Chicago: Chicago University Press, [1953] 1966.

Frey, Bruno S., Silke Humbert and Friedrich Schneider. "Was denken deutsche Ökonomen? Eine empirische Auswertung einer Internetbefragung unter den Mitgliedern des Vereins für Socialpolitik im Sommer 2007." Perspektiven der Wirtschaftspolitik 8, 4 (2007): 359-377.

Fullbrook, Edward. A Guide to What's Wrong in Economics. London: Anthem, 2004.

—. "Economics and Neoliberalism." In After Bhair: Politics after the New Labour Decade edited by Gerry Hassan, pp. 160-171. London: Lawrence and Wishart, 2007.

Fuller, Dan and Doris Geidt-Stevenson, "Consensus Among Economists: Revisited." The Journal of Economic Education 34, 4 (2003): 369-387.

Fusfeld, Daniel R. "A Manifesto for Institutional Economics." Journal of Economic Issues 34 (2000): 257-265.

Garud, Raghu and Peter Karnøe. "Bricololage vs. Breakthrough: Distributed and Embedded Agency in Technology Entrepreneurship." Research Policy 32, 2 (2003): 277-300.

Hayek, Friedrich A. Von. The Road to Serfdom. Chicago: University of Chicago Press, 1944.

-. "Intellectuals and Socialism." In The Intellectuals. A Controversial Portrait edited by George de Huszar, pp. 371-384. Chicago: University of Chicago Press, 1949.

Hayes, Chris. "Hip Heterodoxy." The Nation 2007. Online: http://www.thenation.com/-doc/20070611/ hayes (accessed October 25, 2007).

Helpman, Elhanan and Manuel Trajtenberg. "A Time to Sow and a Time to Reap: Growth based on General Purpose Technologies." Working paper 1080. London: Centre for Economic Policy Research, 1994.

Hicks, John R. "Mr. Keynes and the Classics: A Suggested Interpretation." Econometrica 5 (1937): 147-159.

Hodgson, Geoffrey M. and Harry Rothman. "The Editors and Authors of Economics Journals: A Case of Institutional Oligopoly?" The Economic Journal 109 (1999): F165-F186. 
Kahneman, Daniel and Amos Tversky. "Judgement under Uncertainty: Heuristics and Biases." Science 185 (1974): 1124-1131.

Kahneman, Daniel, Ed Diener and Norbert Schwarz (eds). Well-Being - The Foundations of Hedonic Psychology. New York: Russell Sage Foundation, 1999.

Kapeller, Jakob. Das Menschenbild modemer Ökonomie. Linz: Trauner, 2008.

Katz, Michael L. and Carl Shapiro. "Network Externalities, Competition and Compatibility." The American Economic Review 75, 3 (1985): 424-440.

Keen, Steve. Debunking Economics: The Naked Emperor of the Social Sciences. London: Zed, 2001.

Keynes, John M. The General Theory of Employment, Interest and Money. Amherst, NY: Prometheus Books, 1936.

King, John E. "Three Arguments for Pluralism in Economics." Post-Autistic Economics Review 23 (2004): article 2.

King, Robert G. and Sergio T. Rebelo. "Resuscitating Business Cycles." Working paper 7543. Washington, DC: National Bureau of Economic Research, 2000.

Kuhn, Thomas. The Structure of Scientific Revolutions. Chicago: University of Chicago Press, [1962] 1996.

Lakatos, Imre. "Falsification and the Methodology of Scientific Research Programmes." In Criticism and the Growth of Knowledge, edited by Imre Lakatos and Alan Musgrave, pp. 91-195. Cambridge: Cambridge University Press, 1970.

Lakoff, George and Mark Johnson. Metaphors We Live By. Chicago: University of Chicago Press, 1980.

Lange, Oskar. "Marxian Economics and Modern Economic Theory." Review of Economic Studies 2, 3 (1935): 189-201.

Langlois, Richard N. and Michael J. Everett. "What Is Evolutionary Economics?" In Evolutionary and NeoSchumpeterian Approaches to Economics, edited by Lars Magnusson, pp. 11-47. Dordrecht: Kluwer Academic Publishers, 1994.

Lawson, Tony. "Modern Economics: the Problem and a Solution." In A Guide to What's Wrong in Economics, edited by Edward Fullbrook, pp. 21-32. London: Anthem, 2004.

"The Nature of Heterodox Economics." Cambridge Journal of Economics 30, (2006): 483-505.

Layard, Richard. "Happiness and Public Policy: A Challenge to the Profession." The Economic Joumal 116 (2006): C24-C33.

Lazear, Edward P. "Economic Imperialism." The Quarterly Journal of Economics 115, 1 (2000): 99-146.

Lee, Frederic S. "To Be a Heterodox Economist: The Contested Landscape of American Economics, 1960s and 1970s." Journal of Economic Issues 38 (2004): 747-763.

"A Comment on 'The Citation Impact of Feminist Economics." Feminist Economics 14, 1 (2008a): $137-42$.

"A Case for Ranking Heterodox Journals and Departments." On the Horizon 16, 4 (2008b): 241-251.

. Informational Directory for Heterodox Economists: Graduate and Undergraduate Programs, Journals, Publishers and Book Series, Associations, Blogs, and Institutes and Other. Online: http:// www.heterodoxnews.com/directory/heterodox-directory.pdf (accessed January 20, 2009).

Lee, Frederic S. and Steve Keen. "The Incoherent Emperor: A Heterodox Critique of Neoclassical Microeconomic Theory." Review of Social Economy 62, 2 (2004): 169-199.

Leijonhufvud, Axel. "Life among the Econ." Western Economic Journal 11, 3 (1973): 327.337.

Lippmann, Walter. Public Opinion. New York: First Free Press, [1921] 1997.

Mahoney, James. "Path Dependence in Historical Sociology." Theory and Society 29 (2000): 507.548.

Mankiw, N. Gregory. Grundzüge der Valkswirtschaftslehre. Stuttgart: Schäffer-Poeschel, 2001.

Masterman, Margaret. "The Nature of a Paradigm." In Criticism and the Growth of Knowledge, edited by Imre Lakatos and Alan Musgrave, pp. 59-89. London: Cambridge University Press, 1970.

Merton, Robert K. "The Matthew Effect in Science. The Reward and Communication Systems of Science are Considered." Science 159 (1968): 56-63.

Michie, Jonathan, Christine Oughton and Frank Wilkinson. "Against the New Economic Imperialism." American Journal of Economics and Sociology 61, 1 (2002): 351-365.

Miller, David. "On Methodological Proposals." In Klassiker Auslegen: Logik der Forschung, edited by Herbert Keuth, pp. 67-81. Berlin: Akademie Verlag, 2004.

Minsky, Hyman P. John Maynard Keynes. New York: Columbia Universiry Prcss, [1975] 2008. 
Mirowski, Philip. More Heat than Light: Economics as Social Physics, Physics as Nature's Economics. New York: Cambricge University Press, 1989.

- Machine Dreams. Economics becomes a Cyborg Science. New York: Cambridge University Press, 2008.

Mont Pelerin Society (MPS). Statement of Aims, 1947. Online: http://www.montpelerin.org/ mpsGoals.cfm (accessed February 12 2008).

Nelson, Richard R. and Sidney G. Winter. An Evolutionary Theory of Economic Change. Harvard: Belknap Press, [1982] 1996.

Nordmann, Jürgen. Der lange Marsch zum Neoliberalismus. Hamburg: VSA, 2005.

North, Douglass C. Institutions, Institutional Change and Economic Performance. Cambridge: Cambridge University Press, 1990.

O'Hara, Philip A. "Principles of Institutional-Evolutionary Political Economy - Converging Themes from the Schools of Heterodoxy." Journal of Economic Issues 41, 1 (2007): 1-42.

Osterloh, Margit. "Psychologische Ökonomik und Betriebswirtschaftslehre: Zwischen Modell-Platonismus und Problemotientierung." Keynote at the 70th annual meeting of the German Academic Association for Business Research 2008. Online: https://www.unizh.ch/-iou/orga/ssl-dir/wiki/uploads/Main/ Keynote_VHB08_Papier.pdf (accessed October 10 2008).

Ötsch, Walter. "Bilder der Wirtschaft: Metaphern, Diskurse und Hayeks neoliberales Hegemonialprojekt." In Kapitalismus. Kritische Betrachtungen und Reformansätze, edited by Hubert Hieke, pp. 39-68. Marburg: Metropolis, 2008.

Peukert, Helge. "Der Alltagswissenschaftler aus institutionenökonomischer Sicht." In Die Scheuklappen der Wirtschaftswissenschaft, edited by Thomas Dürmeier, Tanja v. Egan-Krieger and Helge Peukert, pp. 4154. Marburg: Metropolis, 2006.

Plehwe, Dieter. "The Making of a Comprehensive Transnational Discourse Community: The Mont Pèlerin Society of Neoliberal Intellectuals (and think tanks)." Paper presented at the 23rd EGOS Colloquium. July 5-7, 2007, Vienna.

Popper, Karl R. The Poverty of Historicism. London: Routledge, 1957.

- Logik der Forschung, $3^{\text {rd }}$ Edition. Tübingen: Mohr, 1969.

Rabin, Matthew. "A Perspective on Psychology and Economics." Working paper No. E02-313. Department of Economics, University of Berkeley, 2002.

Robbins, Lionel. "The Representative Firm." The Economic Journal 28 (1928): 287-404.

Rutherford, Malcolm. "Institutionalism Between the Wars." Journal of Economic Issues 34 (2000): 291-303.

Samuels, Warren J. "Institutional Economics after One Century." Journal of Economic Issues 34 (2000): 305. 315.

Samuelson, Paul. Principles of Economics, $1^{\text {sc }}$ Edition. New York: McGraw-Hill, 1948.

—. "A Few Remembrances of Friedrich von Hayek (1899-1992)." Joumal of Economic Behavior and Organization 69, 1 (2009): 1-4.

Samuelson, Larry. "Economic Theory and Experimental Economics." Journal for Economic Literature 43 (2005): 65-107.

Schumpeter. Joseph A. Theorie der wirtschaftlichen Entwicklung, Reprint of the $1^{\text {tt }}$ edition. Berlin: Duncker and Humblot, [1912] 2006.

- The Theory of Economic Development. $2^{\text {nd }}$ Edition. With a New Introduction by John E. Elliott. New Brunswick: Transaction Publishers, [1934] 1983.

Screpanti, Ernesto and Stefano Zamagni. An Outline of the History of Economic Thought. Oxford: Clarendon Press, 1995.

Sent, Esther-Mirjam. "Behavioral Economics: How Psychology Made Its (Limited) Way Back Into Economics." History of Political Economy 36, 4 (2004): 735-760.

Shapiro, Carl and Hal R. Varian. Information Rules: A Strategic Guide to the Network Economy. Cumbridge: Harvard Business School Press, 1999.

Siler, Kyle. "The Social and Intellectual Organization and Construction of Economics." Post-Autistic Economics Review 22 (2003): article 3.

Söderbaum, Peter. "The Nobel Prize in Economics - Barrier for New Thinking." Post-Autistic Economics Review 28 (2004): article 5.

Solow, Robert. L'économie entre empirisme et mathématisation. Le Monde, January 32001.

Sraffa, Piero. "The Law of Returns under Competitive Conditions." Economic Journal 40,(1926): 538-550. 
Sterman John D. and Jason Wittenberg. "Path Depence, Competition, and Succesion in the Dynamics of Scientific Revolution." Organization Science 10, 3 (1999): 322-341.

Stigler, George. "Perfect Competition, Historically Contemplated." Journal of Political Economy 65 (1957): 1. 17.

Sydow, Jörg, Georg Schreyögg and Jochen Koch. "Organizational Paths: Path Dependency and Beyond." Paper presented at the 21 st EGOS Colloquium. June 30 - July 2, 2005, Berlin

Vaihinger, Hans. Die Philosophie des als-ob. Aalen: Scienta, [1911] 1986.

Van Bouwel, Jetoen: "Towards a Framework for Pluralism in Economics." Post-Autistic Economics Review 31 (2005): article 3.

Veblen, Thorstein. "Why is Economics not an Evolutionary Science?" The Quarterly Journal of Economics 12, 4 (1898): 373-397.

- Imperial Germany and the Industrial Revolution. New York and London: Macmillan, 1915.

Walpen, Bernhard. Die offenen Feinde und ihre Gesellschaft. Eine hegemonietheoretische Studie zur Mont Pèlerin Society. Hamburg: VSA, 2004.

Whalen, Charles J. "A Reason to Look Beyond Neoclassical Economics: Some Major Shortcomings of Orthodox Theory." Journal of Economic Issues 21 (1987): 259-280.

Willke, Gerhard. Neoliberalismus. Frankfurt: Campus, 2003.

Williamson, Oliver F. The Economic Institutions of Capitalism. New York: The Free Press, 1985.

Ziliak, Stephen T. and Deirdre McCloskey. The Cult of Statistical Significance: How the Standard Error Costs Us Jobs, Justice, and Lives. Ann Arbor: University of Michigan Press, 2008. 